\title{
Point Counts Underestimate the Importance of Arctic Foxes as Avian Nest Predators: Evidence from Remote Video Cameras in Arctic Alaskan Oil Fields
}

\author{
JOSEPH R. LIEBEZEIT ${ }^{1,2}$ and STEVE ZACK ${ }^{1}$
}

(Received 1 March 2007; accepted in revised form 21 September 2007)

\begin{abstract}
We used video cameras to identify nest predators at active shorebird and passerine nests and conducted point count surveys separately to determine species richness and detection frequency of potential nest predators in the Prudhoe Bay region of Alaska. From the surveys, we identified 16 potential nest predators, with glaucous gulls (Larus hyperboreus) and parasitic jaegers (Stercorarius parasiticus) making up more than $80 \%$ of the observations. From the video evidence, however, we identified arctic foxes (Alopex lagopus) as the predators in five of six predation events recorded with the cameras. These results indicate that estimated abundances of predators alone may not accurately reflect their true or proportional importance as nest predators. We also found that the identified predators removed all eggs and left the nests intact. Thus, attempts to identify predators solely on the basis of nest remains are not reliable for smaller bird species in this region. We found no evidence that camera-monitored nests were at greater risk of predation or desertion than camera-free nests. Overall, our ability to film predation events was hampered by the brief, highly synchronized breeding season, the harsh climate, and the higher nest survivorship for shorebirds in this region relative to temperate-breeding passerines, which have been the focus of most studies that use camera systems in attempts to identify nest predators at active nests.
\end{abstract}

Key words: Arctic Alaska, Kuparuk, oil fields, nest predators, nest predation, passerines, Prudhoe Bay, shorebirds, video camera

RÉSUMÉ. Nous avons recouru à des cameras vidéo pour repérer les prédateurs de nids actifs d'oiseaux de rivage et de passériformes, puis nous avons effectué des calculs séparément afin de déterminer la richesse des espèces et la fréquence de détection de prédateurs de nids potentiels dans la région de la baie de Prudhoe, en Alaska. À partir des calculs, nous avons dénombré 16 prédateurs de nids potentiels, les goélands bourgmestres (Larus hyperboreus) et les labbes parasites (Stercorarius parasiticus) représentant plus de $80 \%$ des observations. Cependant, à partir des vidéos, nous avons pu constater que les renards arctiques (Alopex lagopus) étaient les prédateurs dans cinq des six cas de prédation enregistrés au moyen des caméras. Ces résultats laissent croire que seules, les abondances estimées de prédateurs ne reflètent pas nécessairement leur importance véritable ou proportionnelle à titre de prédateurs de nids. Nous avons également constaté que les prédateurs en question prenaient tous les œufs, sans toutefois toucher aux nids. Par conséquent, la possibilité d'identifier les prédateurs seulement en fonction des restes de nids n'est pas fiable dans le cas des plus petites espèces d'oiseaux de cette région. Rien ne nous a laissé croire que les nids surveillés à l'aide d'une caméra étaient plus vulnérables à la prédation ou à l'abandon que les nids n'étant pas dotés de caméras. Dans l'ensemble, la saison de reproduction hautement synchronisée - bien que brève - le climat difficile et le taux de survie en nid plus élevé chez les oiseaux de rivage dans cette région comparativement aux passériformes se reproduisant dans les régions tempérées sur lesquels la plupart des études faisant appel à des caméras se sont concentrées pour repérer les prédateurs de nids actifs ont nuit à notre aptitude à capter les cas de prédation sur vidéo.

Mots clés : Alaska arctique, Kuparuk, champs pétrolifères, prédateurs de nids, prédation de nids, passériformes, baie de Prudhoe, oiseaux de rivage, caméra vidéo

Traduit pour la revue Arctic par Nicole Giguère.

\section{INTRODUCTION}

Nest predation is an important factor in the reproductive success of both passerines (Ricklefs, 1969; Martin, 1993) and shorebirds (Helmers and Gratto-Trevor, 1996). In previous studies in the Prudhoe Bay oil field, Troy (2000) found evidence that population growth in some shorebird species is potentially regulated by nest predation. Abundances of some nest predators, such as arctic fox (Alopex lagopus), glaucous gulls (Larus hyperboreus), and common ravens (Corvus corax), are believed to be higher in Arctic oil fields (versus nearby undisturbed areas) because of the presence of food subsidies and the availability of human structures for nesting and denning (NAS, 2003). The reported increases in predators in these areas may cause elevated nest predation rates (Truett et al., 1997; Day, 1998; NAS, 2003). A key step in managing the impact of increased nest predators is to first identify which predators are the most important.

\footnotetext{
${ }^{1}$ Wildlife Conservation Society, Pacific West Program, 718 SW Alder Street, Suite 210, Portland, Oregon 97205, USA

${ }^{2}$ Corresponding author: jliebezeit@wcs.org

(C) The Arctic Institute of North America
} 
Many researchers have attempted to identify predators from nest remains or signs that predators leave at nests (Hoover et al., 1995; Hernandez et al., 1997; Ivan and Murphy, 2005), but interpretation of this evidence may often lead to erroneous identification (Larivière, 1999; Williams and Wood, 2002). Commonly, no signs are left at apparently depredated nests, making it impossible to identify the predator. In the past 15 years, cameras have increasingly been used to capture predation events on film at both real and artificial nests (Fenske-Crawford and Niemi, 1997; Thompson et al., 1999; Liebezeit and George, 2003). Identifying predators at artificial nests may be misleading because such nests lack parental activity (Skutch, 1949) and nestling begging noise (Leech and Leonard, 1997), and because dummy egg size may influence predator type (Lindell, 2000; Maier and DeGraaf, 2000). Thus, identification of nest predators at real nests is optimal, although not without problems (e.g., potential disturbance to nesting birds).

Despite the recognized importance of nest predation in Arctic ecosystems, especially in human-disturbed areas, little is known about the abundance and identity of nest predators. In addition, most studies using cameras to identify nest predators at active nests have been done at passerine and waterfowl nests; few, if any, cameras have been used to identify shorebird predators. In this study, our objectives were (1) to determine the diversity and detection rate of potential nest predators, (2) to identify nest predators at active shorebird and passerine nests using remote cameras in Arctic Alaskan oil fields, (3) to assess the impact of disturbance on camera-monitored nests by comparing their nest survival rates with those of nearby camera-free nests, and (4) to evaluate the use of nest remains to determine the type of predator.

\section{METHODS}

\section{Study Area}

We conducted fieldwork in the Prudhoe Bay-Kuparuk oil field complex $\left(\sim 70^{\circ} 20^{\prime} \mathrm{N}, 149^{\circ} 00^{\prime} \mathrm{W}\right)$ on the Arctic coastal plain of Alaska. These oil fields border the Arctic Ocean to the north and extend approximately $30 \mathrm{~km}$ inland from the coast. The bulk of the oil field infrastructure, bounded to the east by the Sagavanirktok River and to the west by the Colville River, is composed of a network of gravel roads, pipelines, power lines, production pads, oilprocessing facilities, power stations, and support facilities for oil field personnel. We limited our study area to a $\sim 375 \mathrm{~km}^{2}$ region in Kuparuk and a $400 \mathrm{~km}^{2}$ region in Prudhoe Bay (Fig. 1). At each site, we established 10 ha study plots by first randomly selecting a plot location within the defined study area and then placing subsequent plots systematically with respect to the first one. We sampled 24 plots at Kuparuk for three field seasons (2002 04) and 12 plots at Prudhoe Bay for five field seasons
(2003-07). These efforts are part of a larger study examining the potential impact of oil development on the nest predators and nest survivorship of tundra-nesting birds (Liebezeit et al., unpubl. data).

The topography of this region is generally flat, occasionally interspersed with pingos, and is dominated by numerous ponds and lakes created by the thaw-lake cycle (Walker et al., 1980). The habitat is composed of a gradient of dry, upland tundra to wet tundra with emergent vegetation. Microrelief is characterized by the presence of high and low polygons, hummocks, tussocks, frost boils, and strangmoor ridges (Walker et al., 1980). Mean JuneJuly temperatures from 2002 to 2006 were $\sim 5.5^{\circ} \mathrm{C}$ (Weather Underground, Inc., 2007).

\section{Nest Predator Point Counts}

In each year from 2002 to 2007 , we conducted three sessions (early, mid, and late season) of timed (10-minute) point counts between 12 June and 23 July. Counts were made on Prudhoe Bay plots in all five study years, but on Kuparuk plots only in 2002-04. All counts were performed between 0800 and 2000 Alaska Standard Time (AST). A point count session on each plot consisted of recording all observations of potential nest predators that were detected during $10 \mathrm{~min}$ periods from three fixed locations (at least $200 \mathrm{~m}$ apart) with at least 10 minutes between consecutive counts. We conducted these counts following methods described by Ralph et al. (1993). We estimated the number of predators detected within the plot boundaries as well as predators that occurred outside of the plot up to $300 \mathrm{~m}$ away from the observer. We estimated predator distance from the observer by using rangefinders, by judging the distance using the plot marker stakes as reference points, or by pacing the distance on foot.

We counted only species that have been implicated as potential nest predators in previous studies, and we excluded small rodents (i.e., lemmings and voles) since it is difficult to detect them more than $10 \mathrm{~m}$ from a given point count station. Lemmings have been implicated in nest failure in Lapland longspurs (Calcarius lapponicus) although it is unclear whether they prey on eggs or disrupt nest contents (Custer and Pitelka, 1977).

\section{Nest Discovery and Camera Monitoring}

Each year, we searched for nests between 8 June and 12 July from approximately 0730 to 1800 AST. We used both rope-drag and behavioral nest search techniques to find nests. Once nests were discovered, we visited them every 3-6 days until their fates were determined, following procedures as described by Martin and Geupel (1993).

From 11 June to 23 July, we monitored a subset of the active shorebird and passerine nests for nest predators, using four cameras in 2002, six in 2003-04, and two in 2005-07. We waited until early incubation to set up cameras at nests to avoid causing nest abandonment through 


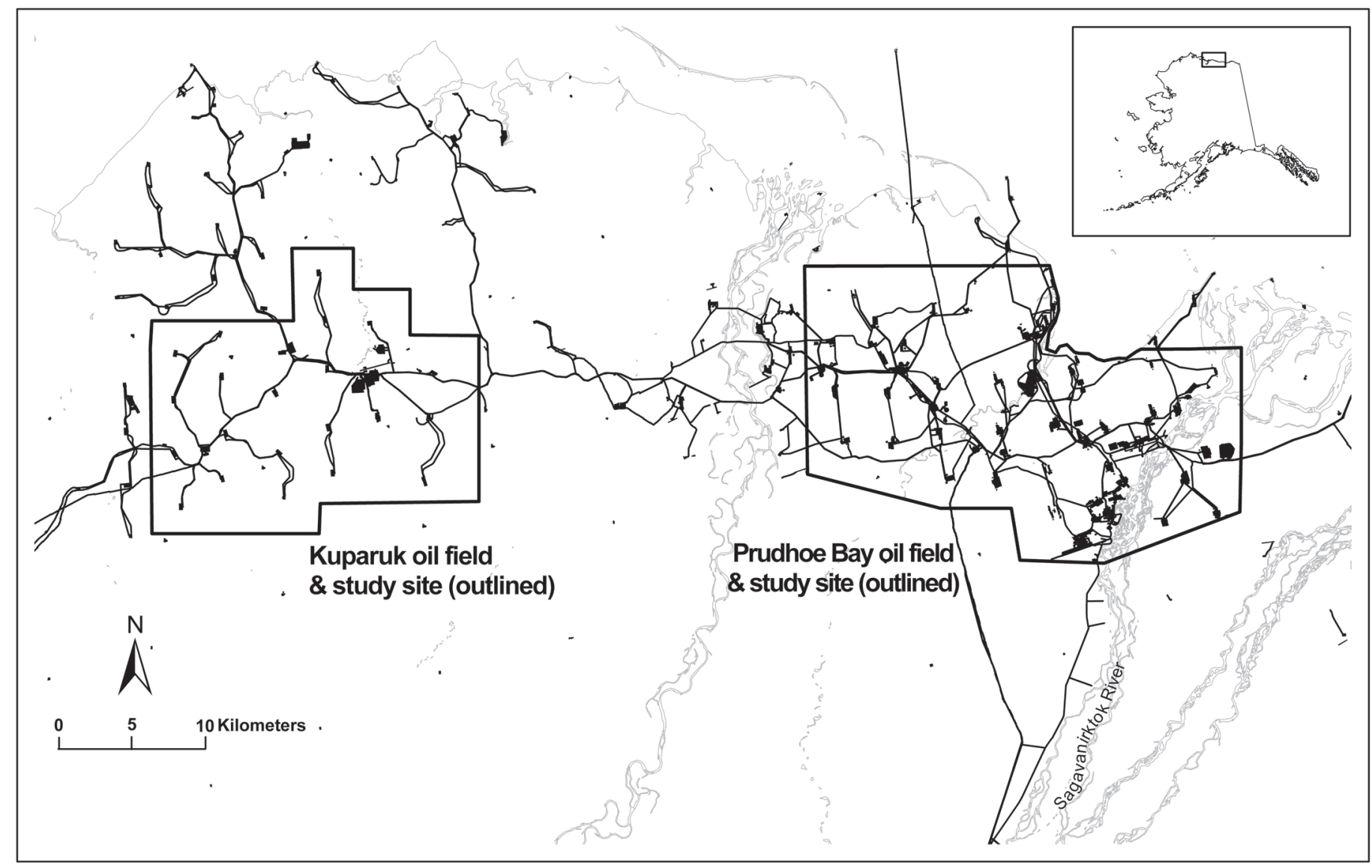

FIG. 1. The Kuparuk and Prudhoe Bay oil fields and accompanying study areas (outlined) sampled for nest predators, North Slope of Alaska. Oil field infrastructure depicted here includes all active roads, pipelines, drilling equipment, and service facilities.

disturbance. We did not use cameras to monitor plover nests because they were considered to be too sensitive to disturbance. We targeted nests in early incubation, but later in the season, we often placed cameras at nests that were in late incubation or the nestling stage (for passerines). We determined the fate of each nest either by checking nests on our regular monitoring visits or by reviewing videotapes. We defined a nest as successful if at least one egg hatched (shorebirds) or if at least one nestling successfully fledged and left the nest (passerines). If a predation event occurred, we typically did not set up a camera on another nest in the same plot to avoid sampling the same predator. We moved a camera from a nest only after the nest became inactive, and we re-established it at a new nest as soon as possible. Within these parameters, we randomly selected nests for monitoring from the pool of discovered nests that fit our sampling criteria. In some cases, we chose nests opportunistically for camera set-up.

We used two types of remote camera systems. From 2002 to 2004, we used a time-lapse videocassette recorder (VCR), wireless camera system developed by Sandpiper Technologies, Inc. This system was composed of two separate units, one at a road-accessible site and the other within a plot at the monitored nest(s). At the road-accessible site, which was typically a pull-out on the side of a road or an unused area near an oil drilling facility, we set up a permanent station to house the VCR and wireless radio receiver. At the nest site(s), we placed up to four weatherproof video cameras at active nests. The zoom capability of the cameras allowed us to install them $5-10 \mathrm{~m}$ from each nest to minimize the likelihood that a given nest predator would associate camera presence with the monitored nest. Each video camera was connected to the same transmitter with a $50 \mathrm{~m}$ cable. Therefore, only nests within a $50 \mathrm{~m}$ radius of the transmitter could be monitored at any one time. The video images were transmitted by line-ofsight via the wireless transmitter system to the roadaccessible site, which was located 0.5 to $8 \mathrm{~km}$ away from the nest sites. The VCR was powered by a $12 \mathrm{~V}$ deep-cycle marine battery, while the cameras and transmitter were powered by a portable $150 \mathrm{~W}$ photovoltaic system linked to a $12 \mathrm{~V}$ battery for power storage. The time-lapse VCR recorded $24 \mathrm{~h}$ of video (five frames per second) on standard T160 VHS videotapes. Videotapes were changed daily, and the $12 \mathrm{~V}$ VCR battery was changed every $48-72 \mathrm{~h}$.

From 2003 to 2007, we employed two Trailmaster ${ }^{\circledR}$ motion-triggered camera systems purchased from Goodson and Associates, Inc. These systems are composed of active infrared transmitter and receiver components and a digital camcorder housed in a protective case. The transmitter and receiver units were mounted on separate tripods and placed on either side of an active shorebird nest, with the infrared 
TABLE 1. Detection frequency of potential nest predators up to $300 \mathrm{~m}$ away from the observer (mean number of individuals observed per 30-minute period from 2002 to 2007) as measured on study plots in the Prudhoe Bay and Kuparuk oil fields, Alaska. Total number of plots sampled each year was 60 at Prudhoe Bay and 72 at Kuparuk. Species are listed in order from most to least detected.

\begin{tabular}{|c|c|c|}
\hline \multirow[t]{2}{*}{ Potential nest predator } & \multicolumn{2}{|c|}{ Site } \\
\hline & Prudhoe Bay oil field (mean \pm SE) & Kuparuk oil field (mean \pm SE) \\
\hline Glaucous gull (Larus hyperboreus) & $1.768 \pm 0.251$ & $1.592 \pm 0.178$ \\
\hline Parasitic jaeger (Stercorarius parasiticus) & $0.950 \pm 0.125$ & $0.651 \pm 0.092$ \\
\hline Long-tailed jaeger (Stercorarius longicaudus) & $0.128 \pm 0.038$ & $0.425 \pm 0.063$ \\
\hline Arctic fox (Alopex lagopus) & $0.172 \pm 0.040$ & $0.062 \pm 0.018$ \\
\hline Common raven (Corvus corax) & $0.095 \pm 0.033$ & $0.051 \pm 0.017$ \\
\hline Pomarine jaeger (Stercorarius pomarinus) & $0.039 \pm 0.024$ & $0.017 \pm 0.008$ \\
\hline Arctic ground squirrel (Spermophilus parryii) & $0.033 \pm 0.028$ & $0.003 \pm 0.003$ \\
\hline Peregrine falcon (Falco peregrinus) & $0.017 \pm 0.009$ & $0.014 \pm 0.010$ \\
\hline Snowy owl (Nyctea scandiaca) & $0.017 \pm 0.009$ & $0.008 \pm 0.006$ \\
\hline Short-eared owl (Asio flammeus) & $0.011 \pm 0.008$ & $0.005 \pm 0.005$ \\
\hline Sandhill crane (Grus canadensis) & $0.011 \pm 0.011$ & 0 \\
\hline Red fox (Vulpes vulpes) & $0.011 \pm 0.011$ & 0 \\
\hline Northern harrier (Circus cyaneus) & $0.006 \pm 0.006$ & $0.005 \pm 0.005$ \\
\hline Sabine's gull (Xema sabini) & $0.006 \pm 0.006$ & 0 \\
\hline Short-tailed weasel (Mustela erminea) & $0.006 \pm 0.006$ & 0 \\
\hline Golden eagle (Aquila chrysaetos) & 0 & $0.005 \pm 0.005$ \\
\hline
\end{tabular}

beam aligned about $0.15 \mathrm{~m}$ above the nest. These units were placed as far from the nest as possible without disrupting the field of view (typically $10-20 \mathrm{~m}$ away). The camcorder was mounted on the same tripod as the receiver. The zoom capability of the camcorder also allowed installation approximately 10-20 m from each nest without sacrificing a good view of the nest area.

We set the transmitter/receiver units at a sensitivity setting to record small to medium-sized animals. We set the camcorder to record for $30 \mathrm{~s}$ when the infrared beam was triggered. We also enabled re-triggering of the camcorder (for another $30 \mathrm{~s}$ ) if another event occurred while it was recording. Lightweight, rechargeable batteries powered all system components. Hi-8 XR-metal 120 professional quality $8-\mathrm{mm}$ camcorder videotapes were used to record footage. The systems were checked every 3-6 days (during nest discovery and monitor visits), and tapes and batteries were changed when necessary.

\section{Statistical Analyses}

We summarized the potential predator detection data to generate the mean number of each species detected per 30 min period within the study area, using the study plot as the sample unit. Because we sampled on the same plots in multiple years, we may have recounted some of the same individuals. We were willing to accept the potential recounting bias since our main goal was to index the predators' use of the study areas and not necessarily to estimate the absolute or relative abundance of predators (Lancia et al., 1996). We conducted a chi-square goodness-of-fit test to compare the observed frequencies of predators recorded by the cameras with the expected frequencies calculated from our point count data.

In order to assess the influence of cameras on nest survivorship, we used Program CONTRAST (Sauer and Williams, 1989) to compare the daily survival rates of camera-monitored and camera-free nests. We calculated daily survival rates using the Mayfield (1975) method and constructed corresponding standard error estimates following methods described by Johnson (1979). We calculated exposure days for the Mayfield estimates using methods recommended by Manolis et al. (2000). We restricted our definition of camera-free nests to those that occurred on the same plots as camera-monitored nests. Survival estimates for camera-monitored nests were calculated only for the actual days when a camera was monitoring the nest.

\section{RESULTS}

During our timed point count surveys, we detected 16 potential nest predator species. The predators detected were predominantly avian, with glaucous gulls and parasitic jaegers (Stercorarius parasiticus), making up more than $80 \%$ of the total detections (Table 1). Arctic foxes were the most common mammalian predator although we detected them relatively infrequently. Using camera systems, we monitored 45 nests of eight different species, for a total of 449 nest observation days on 19 study plots (Table 2). The only passerine species that nested on our study plots was the Lapland longspur. Thirty-two (71\%) of the camera-monitored nests successfully hatched or fledged, nine nests (20\%) were depredated, three nests were still active at the end of the field season when we discontinued monitoring, and one nest was abandoned. We successfully captured predation events at six of the nine depredated nests. Arctic foxes were responsible for five of the six predation events, and a parasitic jaeger for the remaining one (Table 2, Fig. 2). The observed frequency of predator types captured on film was significantly different from what we would have expected on the basis of their frequency calculated from the timed point count data $\left(\chi^{2}=88.66 ; p<0.001\right)$. 
TABLE 2. Species, number of nests monitored, total observation days, number of predation events, and identified nest predators (including date and time of predation) at camera-monitored nests.

\begin{tabular}{|c|c|c|c|c|c|}
\hline Camera-monitored species & $\begin{array}{l}\text { Number of nests } \\
\text { monitored }\end{array}$ & $\begin{array}{l}\text { Total days observed } \\
\text { with camera }\end{array}$ & $\begin{array}{c}\text { Number of } \\
\text { predation events }\end{array}$ & $\begin{array}{l}\text { Identified } \\
\text { predator }\end{array}$ & $\begin{array}{l}\text { Date/time of } \\
\text { predation event }\end{array}$ \\
\hline Dunlin (Calidris alpina) & 3 & 12 & 1 & arctic fox & 18 June2003@19:23 \\
\hline Lapland longspur (Calcarius lapponicus) & 5 & $22 / 29$ & $2^{2}$ & arctic fox & 25 June $2004 @ 01: 57$ \\
\hline Long-billed dowitcher (Limnodromus scolopaceus) & 3 & 32 & 1 & $\operatorname{arctic}$ fox & 18 June $2004 @ 20: 18$ \\
\hline Pectoral sandpiper (Calidris melanotus) & 9 & 94 & 1 & $\mathrm{n} / \mathrm{a}$ & Camera failure \\
\hline Red phalarope (Phalaropus fulicaria) & 2 & 13 & 1 & $\mathrm{n} / \mathrm{a}$ & Camera failure \\
\hline Red-necked phalarope (Phalaropus lobatus) & 7 & 57 & 2 & $\begin{array}{l}\text { parasitic jaeger } \\
\text { arctic fox }\end{array}$ & $\begin{array}{l}\text { 9 July2002@10:25 } \\
\text { 16 June2007@22:10 }\end{array}$ \\
\hline Semipalmated sandpiper (Calidris pusilla) & 13 & 143 & 1 & arctic fox & 18 June $2003 @ 10: 28$ \\
\hline Stilt sandpiper (Calidris himantopus) & 3 & 47 & 0 & $\mathrm{n} / \mathrm{a}$ & $\mathrm{n} / \mathrm{a}$ \\
\hline
\end{tabular}

${ }^{1}$ For Lapland longspur, days observed include incubation and nestling stages.

${ }^{2}$ Only one of these events was recorded due to camera failure.
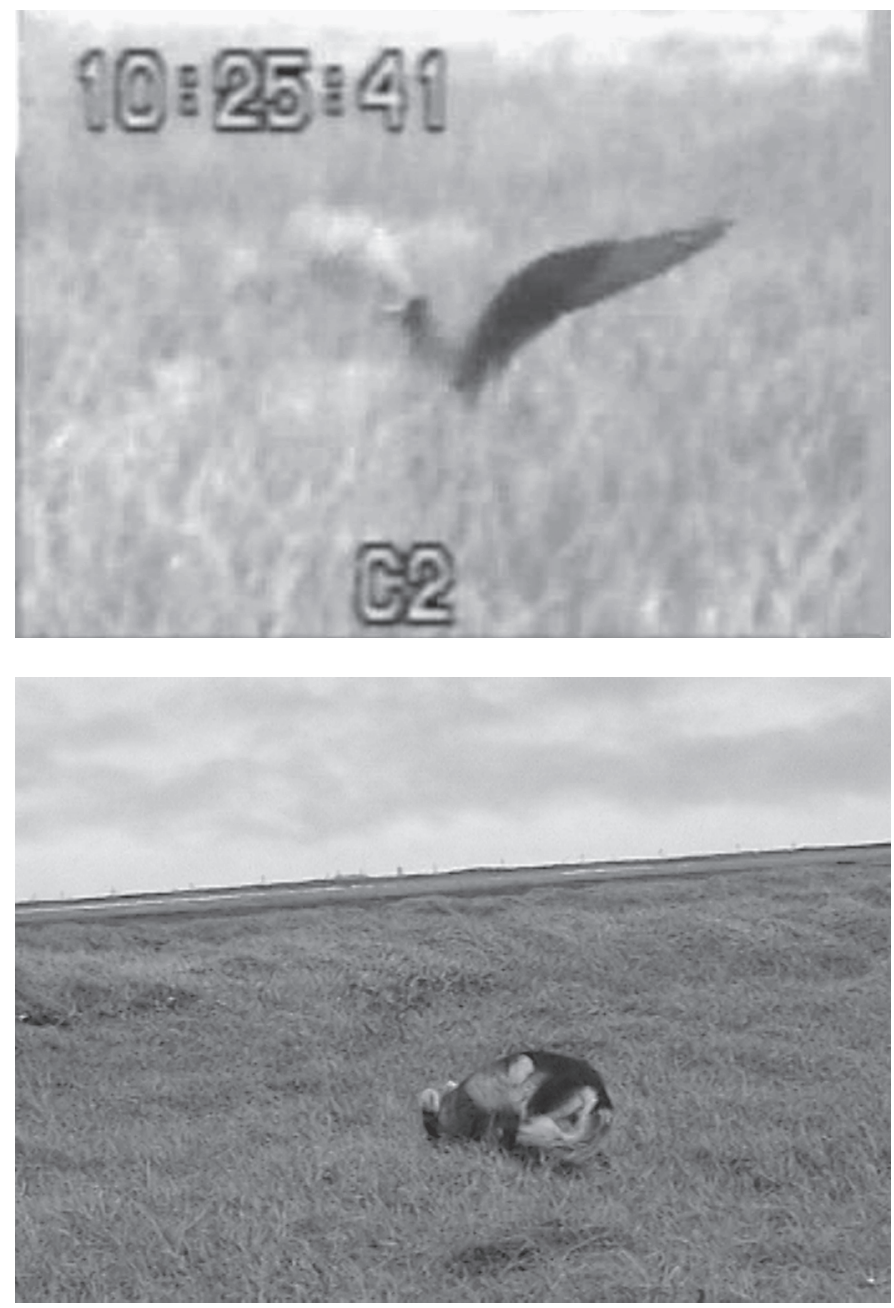

Two fox predation events occurred on 18 June 2003, but we determined from differences in pelage and the $12 \mathrm{~km}$ distance between the two depredated nests that the predators were different foxes. The two nests depredated by foxes on 18 June and 25 June 2004 were on the same study plot, so the same fox may have been responsible. In three of the five fox predation events, the foxes took individual eggs away from the nest on consecutive visits within a 15 min period. These foxes were presumably caching each

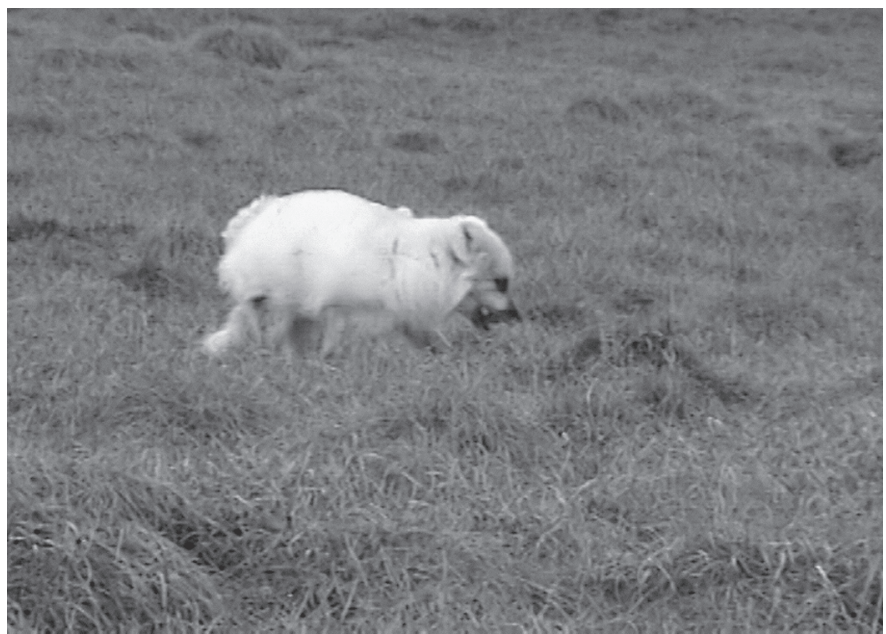

FIG. 2. Sample images captured from nest predation events recorded using remote video camera systems in the Prudhoe Bay and Kuparuk oil fields, including (A) parasitic jaeger arriving at nest moments before depredating rednecked phalarope eggs, (B) arctic fox consuming eggs at a semipalmated sandpiper nest, and (C) arctic fox carrying a dunlin egg from a nest. The fulllength videos of three predation events are available for viewing online at http:/ /www.wcs.org/international/northamerica/alaska/arcticvideoclips.

egg at a nearby location. The three other recorded predators consumed the nest contents at the nest. All recorded predation events occurred during the incubation stage except for the Lapland longspur nest, which was depredated during the nestling stage (nestlings were approximately five days old).

All of the nests depredated by arctic foxes and the parasitic jaeger were left intact with no eggs or egg fragments left in or within $5 \mathrm{~m}$ of the nest. Fox feces were detected at only one of the fox-depredated nests, and no fox urine odor was detected at any fox-depredated nest, although we recorded a fox squatting over a nest and apparently urinating on it just after it consumed the eggs. We detected no urine scent when we visited the nest the following day. Since we had observed in our previous nest monitoring visits that clutch size did not diminish in any of these nests from one visit to the next, we concluded that none of them had been partially depredated. 
TABLE 3. Daily survival rate ( \pm SE), number of observation days, number of nests, and results of program CONTRAST chi-square tests comparing success between camera-monitored and camera-free nests in shorebirds and Lapland longspurs.

\begin{tabular}{|c|c|c|c|c|c|}
\hline Treatment & Daily survival rate $( \pm$ SE) & Number of observed days ${ }^{1}$ & Number of nests & $\chi^{2}$ & $p$ \\
\hline \multicolumn{6}{|l|}{ Shorebirds: } \\
\hline Camera & $0.980 \pm 0.007$ & 398 & 40 & 0.55 & 0.46 \\
\hline Camera-free & $0.974 \pm 0.004$ & 1537 & 139 & & \\
\hline \multicolumn{6}{|c|}{ Lapland longspur: } \\
\hline Camera & $0.961 \pm 0.027$ & 51 & 5 & 0.001 & 0.99 \\
\hline Camera-free & $0.961 \pm 0.011$ & 593 & 54 & & \\
\hline
\end{tabular}

${ }^{1}$ For shorebirds, number of days observed includes the incubation stage only; for Lapland longspurs, we combined incubation and nestling stages.

Two of the three predation events we missed occurred while we were using the wireless time-lapse VCR system. In one instance, we missed a predation event because of power failure; probably the solar energy produced in overcast weather was insufficient for battery recharge. In the other case, the transmitting antennae for the system blew down in high winds, and the predation event took place before we were able to re-orient the antennae. The one predation event we missed with the Trailmaster ${ }^{\circledR}$ system occurred because the tape ran out. At all three of these nests, there was no indication as to the identity of the predator. The nests were left intact and no egg remnants were detected in the area.

In addition to the camera-monitored nests, we also monitored 193 camera-free nests of the same target species on the same plots. We detected no significant difference between camera-monitored and camera-free nests in the daily survival rate of either shorebird species or Lapland longspurs (Table 3 ).

\section{DISCUSSION}

We used traditional point count methods to determine the species richness and detection frequency of a suite of potential nest predators, both avian and mammalian. We found this method to work well in tundra habitat because of excellent visibility (lack of trees and flat topography). The distance may have compromised our ability to detect smaller predators such as the short-tailed weasel (Mustela erminea), but most of the predators in this region are relatively large-bodied and were easily detectable within the range of our point counts. It is important to note that these surveys may be biased against detecting arctic foxes because, despite the continual sunlight in this region during the Arctic summer, they are typically most active nocturnally (Eberhardt et al., 1982). Other confirmed or suspected nest predators that have been documented in this region but were not detected during our surveys include brown bear (Ursus arctos; Stickney and Ritchie, 1996), polar bear (Ursus maritimus; Rubega et al., 2000), and wolverine (Gulo gulo; Lanctot and Laredo, 1994).

Although the predator point count surveys indicate that avian predators are more numerous than mammalian predators, the result of camera-identified predators suggests that the most important predator of shorebirds and passerines in this region is the arctic fox. Our sample size of recorded predation events was small, however, so we encourage further study to confirm this tentative conclusion. Only a handful of studies conducted in the Arctic have attempted to identify nest predators using remote cameras, and none have previously been conducted at shorebird nests. Hawkins (1986) used camera systems to monitor tundra swan (Cygnus columbianus) nests on the Colville River Delta and found arctic foxes to be the most important nest predators, although the swans often successfully defended nests from foxes. Using a remote movie camera, Custer (1973) identified a snowy owl (Nyctea scandiaca) depredating Lapland longspur nestlings at a site near Barrow. Johnson et al. (1993) used cameras to monitor nest predators in snow goose (Chen caerulescens) colonies on Howe Island. They reported significant arctic fox activity; however, no predators were caught on film while depredating nests. From 1998 to 2003, 15 spectacled eider (Somateria fischeri) nests were video-monitored in the Kuparuk oil field (B. Anderson, pers. comm. 2007). Three nests failed, but only one event, an arctic fox predation, was successfully recorded. Rojek et al. (2006), using remote video cameras, documented pomarine jaegers (Stercorarius pomarinus) depredating two Steller's eider (Polysticta stelleri) nests near Barrow, Alaska, but recorded no fox predation; however, 17 arctic foxes were removed during the study in an effort to reduce a known predator. Three of five of these previous studies corroborate the importance of arctic foxes as nest predators.

Researchers commonly use the presence of fox fecal matter or the smell of fox urine at a nest site as an indication of predator identity (Murphy et al., 1990; Troy, 1993; Anderson and Cooper, 1994). Nest site remains are also frequently used as an indicator of the type of nest predator: disturbed nest remains are often thought to indicate a large mammalian predator, while depredation of a nest left intact is often attributed to birds, snakes, or small mammals (Best and Stauffer, 1980; Wray et al., 1982; Hoover et al., 1995). Our results give little support for these predator identification methods since for the one jaeger and five fox predation events that we recorded, nests remained intact and undisturbed. Moreover, we documented fresh arctic fox feces left at nests (primarily waterfowl nests) from which the birds 
had departed just days before. In at least five cases, these nests were known to have successfully hatched. It is possible that residual egg remains (and the accompanying odor) left at the inactive nests may attract arctic foxes as scavengers. For waterfowl, it may be reliable to determine predator type, sometimes to species, by examining puncture and bite marks in eggs left at depredated nests (Sargeant et al., 1998; Quakenbush et al., 2004; Anthony et al., 2006). For smaller birds (shorebirds and passerines), it is generally not possible to use this method, since large egg pieces with discernable puncture marks are rarely left in depredated nests. We recommend that biologists exercise caution in future studies when speculating on the identity of nest predators on the basis of nest condition or the presence of fox sign, or both.

Our comparison of daily survival rates at camera-monitored versus camera-free nests suggests that predators neither were attracted to camera-monitored nests nor avoided them. Cartar and Montgomerie (1985) used cameras to monitor incubation scheduling of the white-rumped sandpiper (Calidris fuscicollis) in the Canadian Arctic and documented higher predation at the camera-monitored nest compared to camera-free nests. Other researchers in similarly open habitats (temperate grasslands/fields) using cameras on active passerine nests found either no camera effect on survival or higher survival at cameramonitored nests (Thompson et al., 1999; Pietz and Granfors, 2000). However, one main difference between these studies and ours is that cameras were typically placed within $2 \mathrm{~m}$ of the nest rim. Although we documented no influence of the cameras on nest survivorship, on at least one occasion we observed an arctic fox inspecting deployed camera equipment, and in two cases, we discovered that camera wires had been chewed.

In contrast to some previous studies (Thompson et al., 1999; Pietz and Granfors, 2000; Renfrew and Ribic, 2003), our study found that camera placement at nest sites did not cause significant nest abandonment. Only one of our camera-monitored nests was abandoned, but it is likely that this happened before we set up the camera system. We recommend that other researchers place cameras at least $5 \mathrm{~m}$ from the monitored nest in similar open habitats where camera equipment is difficult to conceal. However, this distance may make it difficult to detect small predators. We were willing to accept this potential bias since most suspected predators at the site are relatively large-bodied.

Considering the effort involved, we had relatively poor success in capturing predation events for a number of reasons. We employed relatively few cameras during the brief Arctic breeding season. The opportunity to set up the camera on a second nest if the previously monitored nest was successful was rare because of synchronous breeding and the virtual absence of second nesting efforts. Also, for shorebird species, nesting success was relatively high at our sites compared to those reported in most cameramonitoring studies of passerine species (e.g., Thompson et al., 1999; Pietz and Granfors, 2000; Liebezeit and George, 2002). Thus, most monitored nests were never visited by a predator. Finally, we experienced frequent camera problems, which were responsible for the three predation events we were unable to record at camera-monitored nests. Other researchers using similar camera systems have reported more reliable performance (Brown et al., 1998; Thompson et al., 1999; Stake and Cimprich, 2003; Stake et al., 2004). These researchers conducted their studies in temperate regions, and thus more hospitable weather conditions may have contributed to their success.

In conclusion, first, we caution that surveys of potential nest predators in a given region may not accurately represent the importance of actual nest predators. Second, our camera-monitoring results lend further support to other studies from this region indicating that arctic fox may be the most important nest predator, not only for waterfowl, but for smaller nesting birds. Third, we found that the identified predators removed all eggs and left the nests intact—and in some cases, foxes marked nests they found after the birds had vacated them; therefore, attempts at identifying predators from nest remains are not reliable for smaller bird species in this region. Finally, we found that capturing predation events by means of camera systems is challenging in an Arctic environment, and both efforts and success are constrained by the brief breeding season and harsh climate.

\section{ACKNOWLEDGEMENTS}

We thank our many field assistants, especially Amy Leist, for their hard work in the field. We also thank BP and ConocoPhillips, Inc. for allowing access to our study areas and providing room and board for the field assistants. Funding was provided by grants from the Neotropical Migratory Bird Conservation Act (U.S. Fish and Wildlife Service), Disney Wildlife Conservation Fund, Liz Claiborne/Art Ortenberg Foundation, private donors, and by the Wildlife Conservation Society. We thank Paul Smith, Lori Quakenbush, and an anonymous reviewer for providing helpful comments and improving the manuscript.

\section{REFERENCES}

ANDERSON, B.A., and COOPER, B.A. 1994. Distribution and abundance of spectacled eiders in the Kuparuk and Milne Point oilfields, Alaska, 1993. Final report prepared for ARCO Alaska, Inc. and the Kuparuk River Unit, Anchorage, AK, by Alaska Biological Research Associates, Inc., P.O. Box 80410, Fairbanks, Alaska 99708. $61 \mathrm{p}$.

ANTHONY, R.M., GRAND, J.B., FONDELL, T.F., and MILLER, D.A. 2006. Techniques for identifying predators of goose nests. Wildlife Biology 12(3):249-256.

BEST, L.B., and STAUFFER, D.F. 1980. Factors affecting nesting success in riparian bird communities. Condor 82(2):149-158.

BROWN, K.P., MOLLER, H., INNES, J., and JANSEN, P. 1998. Identifying predators at nests of small birds in a New Zealand forest. Ibis 140:274-279. 
CARTAR, R.V., and MONTGOMERIE, R.D. 1985. The influence of weather on incubation scheduling of the white-rumped sandpiper (Calidris fuscicollis): A uniparental incubator in a cold environment. Behaviour 95:261 - 289.

CUSTER, T.W. 1973. Snowy owl predation on Lapland longspur nestlings recorded on film. Auk 90(2):433-435.

CUSTER, T.W., and PITELKA, F.A. 1977. Demographic features of a Lapland longspur population near Barrow, Alaska. Auk 94(3):505-525.

DAY, R.H. 1998. Predator population and predation intensity on tundra-nesting birds in relation to human development. Report prepared for Northern Alaska Ecological Services, U.S. Fish and Wildlife Service, Fairbanks, by Alaska Biological Research Associates, Inc., P.O. Box 80410, Fairbanks, Alaska 99708. $106 \mathrm{p}$.

EBERHARDT, L.E., HANSON, W.C., BENGTSON, J.L., GARROTT, R.A., and HANSON, E.E. 1982. Arctic fox home range characteristics in an oil-development area. Journal of Wildlife Management 46(1):183-190.

FENSKE-CRAWFORD, T.J., and NIEMI, G.J. 1997. Predation of artificial ground nests at two types of edges in a forest-dominated landscape. Condor 99(1):14-24.

HAWKINS, L.L. 1986. Nesting behavior of male and female whistling swans and implications of male incubation. Wildfowl 37:5-27.

HELMERS, D.L., and GRATTO-TREVOR, C.L. 1996. Effects of predation on migratory shorebird recruitment. Transactions of the 61st North American Wildlife and Natural Resources Conference 61:50-61.

HERNANDEZ, F., ROLLINS, D., and CANTU, R. 1997. Evaluating evidence to identify ground-nest predators in west Texas. Wildlife Society Bulletin 25(4):826-831.

HOOVER, J.P., BRITTINGHAM, M.C., and GOODRICH, L.J. 1995. Effects of forest patch size on nesting success of wood thrushes. Auk 112(1):146-155.

IVAN, J.S., and MURPHY, R.K. 2005. What preys on piping plover eggs and chicks? Wildlife Society Bulletin 33(1): $113-119$.

JOHNSON, D.H. 1979. Estimating nest success: The Mayfield method and an alternative. Auk 96(4):651-661.

JOHNSON, S.R., RODRIGUES, R.J., and POLLARD, R.H. 1993. Video analysis of predators and nesting snow geese on Howe Island, Sagavanirktok River Delta, Alaska, 1992. Report to BP Exploration [Alaska], Inc., by LGL Alaska Research Associates, Inc., 1101 E. 76th Avenue, Suite B, Anchorage, Alaska 99518. $9 \mathrm{p}$.

LANCIA, R.A., NICHOLS, J.D., and POLLOCK, K.H. 1996. Estimating the number of animals in wildlife populations. In: Bookhout, T.A., ed. Research and management techniques for wildlife habitats. 5th ed. Bethesda, Maryland: The Wildlife Society. 740 p.

LANCTOT, R.B., and LAREDO, C.D. 1994. Buff-breasted sandpiper (Tryngites subruficollis). In: Poole, A., and Gill, F. eds. The birds of North America, No. 91. Philadelphia: The Academy of Natural Sciences and Washington, D.C.: The American Ornithologists' Union.
LARIVIÈRE, S. 1999. Reasons why predators cannot be inferred from nest remains. Condor 101(3):718-721.

LEECH, S.M., and LEONARD, M.L. 1997. Begging and the risk of predation in nestling birds. Behavioural Ecology 8(6):644-646.

LIEBEZEIT, J.R., and GEORGE, T.L. 2002. Nest predators, nestsite selection, and nesting success of the dusky flycatcher in a managed ponderosa pine forest. Condor 104(3):507-517.

. 2003. Comparison of mechanically egg-triggered cameras and time-lapse video camera systems in identifying predators at active dusky flycatcher nests. Journal of Field Ornithology 74(3):261-269.

LINDELL, C. 2000. Egg type influences predation rates in artificial nest experiment. Journal of Field Ornithology 71(1):16-21.

MAIER, T.J., and DEGRAAF, R.M. 2000. Predation on Japanese quail vs. house sparrow eggs in artificial nests: Small eggs reveal small predators. Condor 102(2):325-332.

MANOLIS, J.C., ANDERSEN, D.E., and CUTHBERT, F.J. 2000. Uncertain nest fates in songbird studies and variation in Mayfield estimation. Auk (3)117:615-626.

MARTIN, T.E. 1993. Nest predation and nest sites: New perspectives on old patterns. Bioscience 43(8):523-532.

MARTIN, T.E., and GEUPEL, G.R. 1993. Nest-monitoring plots: Methods for locating nests and monitoring success. Journal of Field Ornithology 64(4):507-519.

MAYFIELD, H.F. 1975. Suggestions for calculating nest success. Wilson Bulletin 87(4):456-466.

MURPHY, S.M., ANDERSON, B.A., CRANOR, C.L., JORGENSON, M.T., and LANCE, B.K. 1990. Lisburne terrestrial monitoring program-1989. The effects of the Lisburne development project on geese and swans. 5th Annual Report. Prepared for ARCO Alaska, Inc., Anchorage, AK, by Alaska Biological Research Associates, Inc., P.O. Box 80410, Fairbanks, Alaska 99708.

NAS (NATIONAL ACADEMY OF SCIENCES). 2003. Cumulative environmental effects of oil and gas activities on Alaska's North Slope. National Research Council of the National Academies. Washington D.C.: National Academies Press.

PIETZ, P.J., and GRANFORS, D.A. 2000. Identifying predators and fates of grassland passerine nests using miniature video cameras. Journal of Wildlife Management 64(1):71-87.

QUAKENBUSH, L., SUYDAM, R., OBRITSCHKEWITSCH, T., and DEERING, M. 2004. Breeding biology of Steller's eiders (Polysticta stelleri) near Barrow, Alaska, 1991-99. Arctic 57(2):166-182.

RALPH, C.J., GEUPEL, G.R., PYLE, P., MARTIN, T.E., and DESANTE, D.F. 1993. Handbook of field methods for monitoring landbirds. General Technical Report PSW-GTR-144. Albany, California: Pacific Southwest Research Station, Forest Service, U.S. Department of Agriculture. 41 p.

RENFREW, R.B., and RIBIC, C.A. 2003. Grassland passerine nest predators near pasture edges identified on videotape. Auk 120(2):371-383.

RICKLEFS, R.E. 1969. An analysis of nesting mortality in birds. Smithsonian Contributions to Zoology 9:1-48.

ROJEK, N., MARTIN, P., and GOERKE, R. 2006. Video monitoring to determine nest fate of Steller's eiders in northern Alaska. Final report to the Alaska SeaLife Center by the U.S. Fish and 
Wildlife Service, 101 12th Avenue, Fairbanks, Alaska 99701. $21 \mathrm{p}$.

RUBEGA, M.A., SCHAMEL, D., and TRACY, D.M. 2000. Rednecked phalarope (Phalaropus lobatus). In: Poole, A., and Gill, F., eds. The birds of North America, No. 538. Philadelphia: The Birds of North America, Inc.

SARGEANT, A.B., SOVADA, M.A., and GREENWOOD, R.J. 1998. Interpreting evidence of depredation of duck nests in the prairie pothole region. Jamestown, North Dakota: United States Geological Survey, Northern Prairie Wildlife Research Center, and Memphis, Tennessee: Ducks Unlimited. 72 p.

SAUER, J.R., and WILLIAMS, B.K. 1989. Generalized procedures for testing hypotheses about survival or recovery rates. Journal of Wildlife Management 53:137-142.

SKUTCH, A.F. 1949. Do tropical birds rear as many young as they can nourish? Ibis 91:430-455.

STAKE, M.M., and CIMPRICH, D.A. 2003. Using video to monitor predation at black-capped vireo nests. Condor 105(2):348-357.

STAKE, M.M., FAABORG, J., and THOMPSON, F.R., III. 2004. Video identification of predators at golden-cheeked warbler nests. Journal of Field Ornithology 75(4):337-344.

STICKNEY, A.A., and RITCHIE, R.J. 1996. Distribution and abundance of brant (Branta bernicla) on the central Arctic coastal plain of Alaska. Arctic 49(1):44-52.

THOMPSON, F.R., III, DIJAK, W., and BURHANS, D.E. 1999. Video identification of predators at songbird nests in old fields. Auk 116(1):259-264.
TROY, D.M. 1993. Population dynamics of birds in the Pt. McIntyre reference area 1981 - 1992. Report prepared for BP Exploration (Alaska), Inc., Anchorage, by Troy Ecological Research Associates, 2322 E. 16th Avenue, Anchorage, Alaska 99508.

2000. Shorebirds. In: Truett, J.C., and Johnson, S.R., eds. The natural history of an Arctic oil field: Development and biota. San Diego: Academic Press. 277-304.

TRUETT, J.C., MILLER, M.E., and KERTELL, K. 1997. Effects of Arctic Alaska oil development on brant and snow geese. Arctic 50(2):138-146.

WALKER, D.A., EVERETT, K.R., WEBBER, P.J., and BROWN, J. 1980. Geobotanical atlas of the Prudhoe Bay region, Alaska. CRREL Report 80-14. Hanover, New Hampshire: United States Army Corps of Engineers, Cold Regions Research and Engineering Laboratory.

WEATHER UNDERGROUND, INC. 2007. Daily weather recorded at Deadhorse Airport, Prudhoe Bay, Alaska 2002-2006. http:// www.wunderground.com/history/airport/PASC/.

WILLIAMS, G.E., and WOOD, P.B. 2002. Are traditional methods of determining nest predators and nest fates reliable? An experiment with wood thrushes (Hylocichla mustelina) using miniature video cameras. Auk 119(4):1126-1132.

WRAY, T., II, STRAIT, K.A., and WHITMORE, R.C. 1982. Reproductive success of grassland sparrows on a reclaimed surface mine in West Virginia. Auk 99(1):157-164. 